A N N A LES

UNIVERSITATIS MARIAE CURIE-SKŁODOWSKA LUBLIN - POLONIA

VOL. XV, 2

SECTIO L 2017

Instytut Filozofii Uniwersytetu Śląskiego w Katowicach

BŁAŻEJ MAREK ZYCH

\title{
Wzór klasyczny a człowiek masowy w ujęciu współczesnych teoretyków spoteczeństwa i kultury: \\ Daniela Bella, Allana Blooma oraz Jose Ortegi y Gasseta
}

The Classic Pattern and Mass Man as Interpreted by the Contemporary Theorists of Society and Culture: Daniel Bell, Allan Bloom, and Jose Ortega y Gasset

W toku studiów artystycznych oraz filozoficznych zainteresowałem się twórczością współczesnych myślicieli poruszających tematykę sztuki, której wątki były dla mnie zagadkowe. Celem artykułu jest przedstawienie założeń konserwatyzmu kulturowego. Poniżej prezentuję genezę upadku współczesnej kultury. Trzech autorów objaśnia ten obraz w sposób wielowymiarowy. Bloom wskazuje na korzenie filozoficzne, począwszy od renesansu. Ortega y Gasset analizuje modernizm, a Bell zwraca uwagę na jego efekty w latach sześćdziesiątych XX wieku. Dla Ortegi y Gasseta, jak i Blooma poszukiwanie, świadomość nieznanego i prawdziwego pełni istotną rolę. Dla Hiszpana inspirującą postacią jest błędny rycerz Don Kichot, o którym napisał Medytacje. Bloom natomiast dumając nad Odyseją Homera, dzieli się swoimi wątpliwościami, czy są jeszcze ludzie będący w stanie podjąć się wyzwania, jakie stało przed Odysem. Aby było to możliwe, musi być podtrzymana międzypokoleniowa więź, która umożliwi młodszym generacjom zrozumienie sztuki czasów minionych. Jakie są więc główne tezy klasyczne oraz co doprowadziło do tego, że pamięć o fundamentach kultury europejskiej zanika? 
Pobrane z czasopisma Annales L - Artes http://artes.annales.umcs.pl

Data: 26/04/2023 06:58:32

\section{Ujęcie klasyczne}

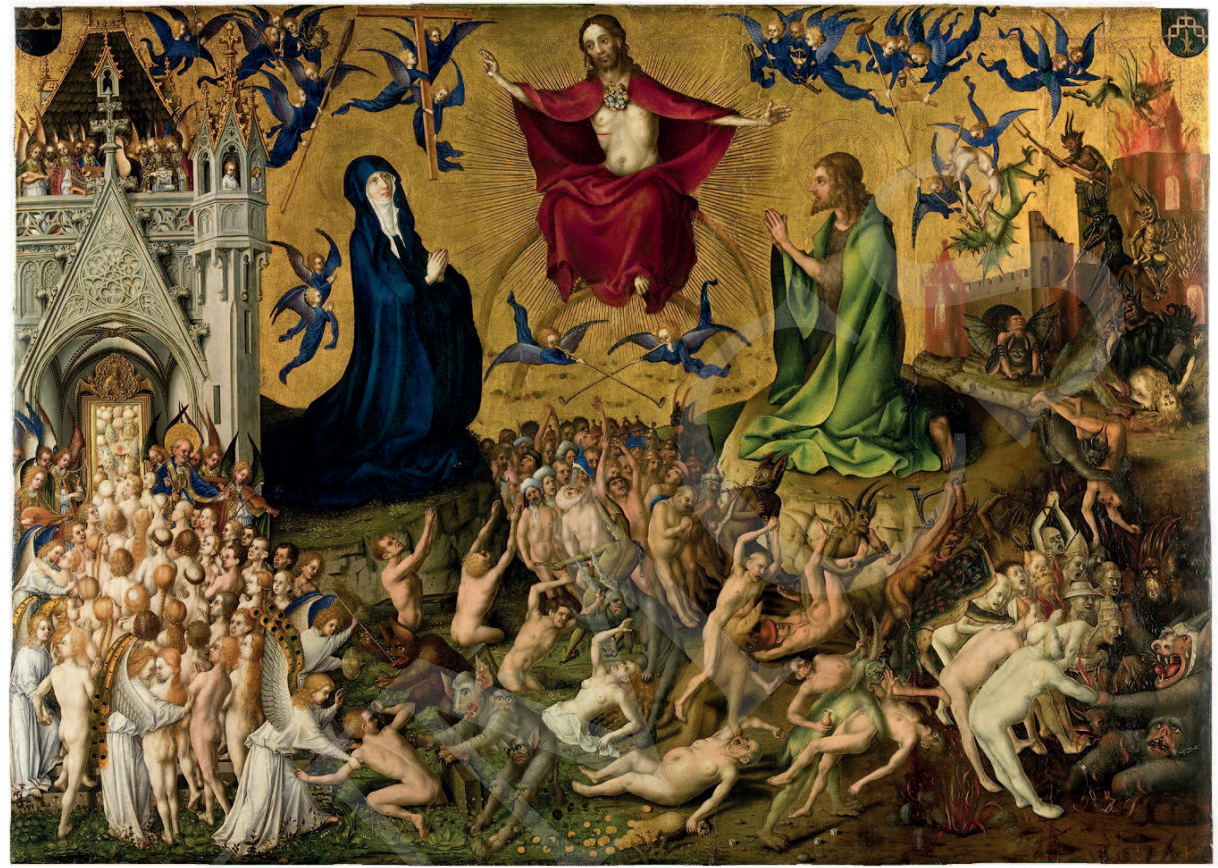

Ilustr. 1. Stefan Lochner, Sąd Ostateczny, ok. 1435, źródło: wikipedia.org.

Patrząc wstecz, dostrzegamy, że każda epoka wytwarzała styl artystyczny najlepiej odbijający ówczesną wrażliwość, który - będąc stylem współczesnym - był także kontynuacją sztuki dawniejszej. Sztuka tradycyjna wskazywała nowemu pokoleniu, co ma robić. Te aspekty, które w sztuce przeszłości nie były podkreślone czy należycie wykorzystane, stawały się inspiracją dla następnego pokolenia. Przykłady nasuwają się same, np. koncepcje teologiczne w Sądzie Ostatecznym Stefana Lochnera $\mathrm{z}$ Katedry w Kolonii, gdzie ludzie zmartwychwstają prosto ze swoich ziemskich grobów, a z drugiej strony Pogrzeb hrabiego Orgaza pędzla El Greco, gdzie dusza niedawno zmarłego Don Gonzalo Ruiza z Toledo pojawia się w ramionach anioła w postaci delikatnie zarysowującego się „obłoku”.

$\mathrm{Na}$ obu obrazach figuratywnych pojawiają się wizje zupełnie innych losów człowieka. Praca nad tym tworzywem zakładała utrzymanie w mocy ogólnych podstaw sztuki tradycyjnej. Trafnie określił to Ortega y Gasset: 
Pobrane z czasopisma Annales L - Artes http://artes.annales.umcs.pl

Data: 26/04/2023 06:58:32

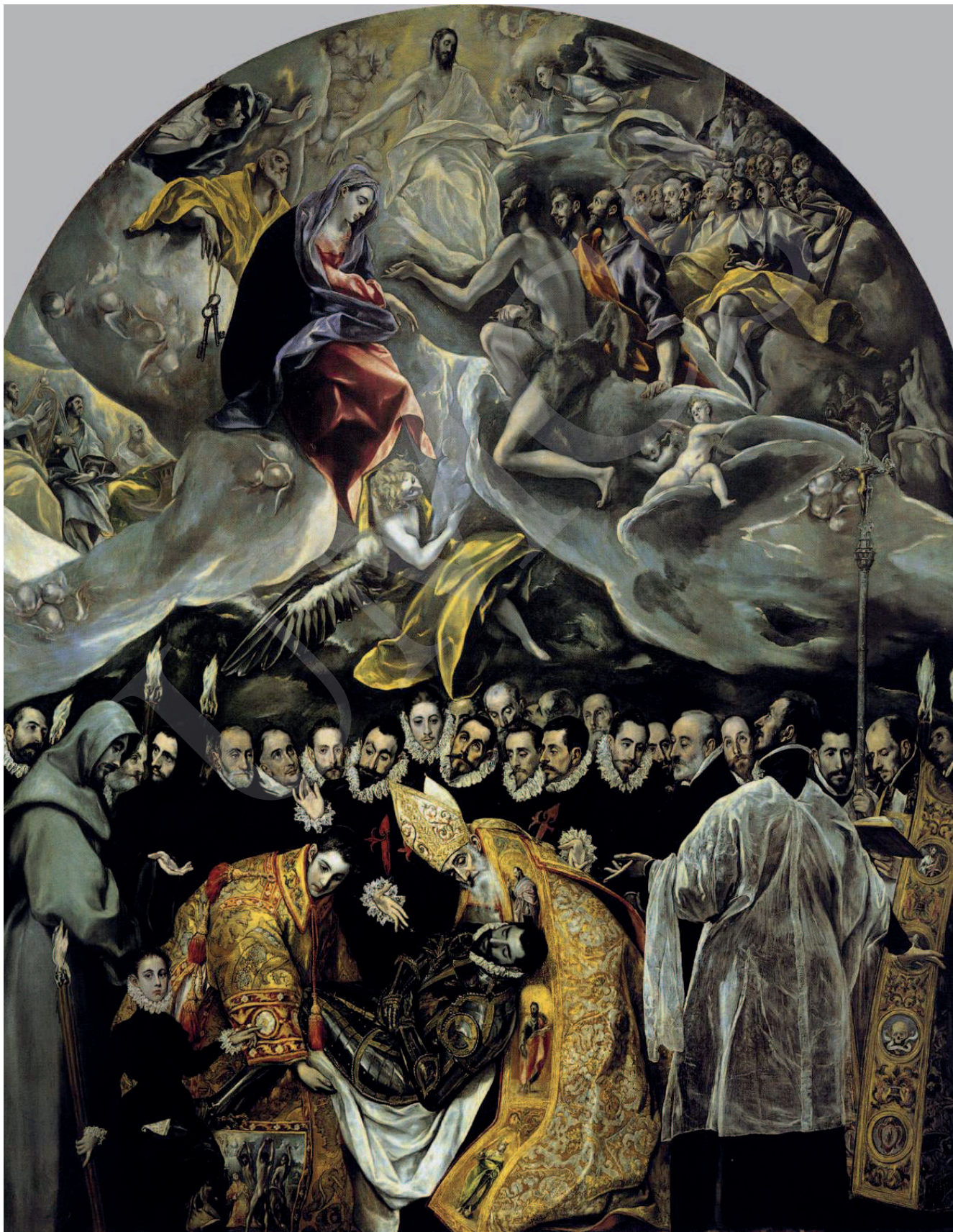

Ilustr. 2. El Greco, Pogrzeb Hrabiego Orgaza, ok. 1586-1588, źródło: wikipedia.org. 
„Chodziło tu o ewolucję, o ciągłe modyfikacje, jakim poddawane było niezmienne jądro tradycji. To, co było nowe i współczesne, miało być, przynajmniej w zamierzeniach, zupełnie jawne i zrozumiałe, stając się żywym pomostem pomiędzy przeszłością a teraźniejszością"1.

Co było w takim razie zwornikiem przeżyć ludzkich? Spójność tradycji pokazuje Bell, poszukując przejawów kultury w sytuacjach egzystencjalnych, z jakimi niezależnie od epoki ma do czynienia każdy człowiek. Napisał, że:

„Dotyczą tego, jak się spotyka śmierć, natury tragedii i bohaterstwa, definicji lojalności i obowiązku, zbawienia duszy, sensu miłości i poświęcenia, rozumienia współczucia, napięcia między tym, co zwierzęce i ludzkie w naturze człowieka, między instynktem a jego ograniczeniami”’.

Poszukując początków sztuki kręgu europejskiego, powinniśmy przytoczyć, co na ten temat myśleli Grecy. Sztuka miała naśladować jedynie piękne ciała. Przedmiotem dzieł greckiego artysty jest piękno. Trzeba zwrócić uwagę, że piękno niższego rzędu, pospolite, było co najwyżej przyczynkiem do ćwiczeń. Dzieło musiało zachwycać doskonałością danego przedmiotu. Samo uchwycenie podobieństwa świadczące o zręczności malarza nie wystarczało. Najważniejszy, najszlachetniejszy był cel ostateczny. Klasyczną zasadą regulującą estetyczne intencje zachodniej sztuki i literatury była koncepcja mimesis, czyli przedstawienie rzeczywistości poprzez jej naśladowanie. Sztuka miała być zwierciadłem natury, przedstawieniem życia. Tradycja utożsamiała zawsze autentyczność $\mathrm{z}$ autorytetem, mistrzostwem w rzemiośle, znajomością formy, poszukiwaniem moralnej bądź estetycznej doskonałości. Wiedzę z kolei traktowano jako odzwierciedlenie rzeczywistości, kopię przedmiotów obserwowanych, postrzeganych zmysłowo. Osądy miały w zasadzie charakter kontemplacyjny, a mimesis świadczyła o ich wartości.

Zamierzeniem estetyki nowożytnego świata zachodniego od XV do połowy XIX wieku była kontynuacja tworzenia jasnych formalnych zasad sztuki. Ustalono wewnętrzny dystans przestrzenny: plan pierwszy i tło, postać oraz poczucie proporcji i miary, które tworzyły porządek oraz następstwo czasu, czyli początek, rozwinięcie i zakończenie. Renesansowe malarstwo, którego zasady zostały określone m. in. przez Albertiego, charakteryzowało się racjonalnością. Stosowało formalne zasady matematyczne w przedstawianiu sceny: proporcje i perspektywę. Usiłowało przełożyć na sztukę racjonalną kosmografię przestrzeni jako głębi

${ }^{1}$ J. Ortega y Gasset, Dehumanizacja sztuki i inne eseje, tłum. P. Niklewicz, Warszawa 1996, s. 165 .

${ }^{2}$ D. Bell, Kulturowe sprzeczności kapitalizmu, tłum. S. Amsterdamski, Warszawa 1998, s. 47. 
i czasu, jako następstwa. Renesansowa koncepcja przestrzeni została następnie ugruntowana w Newtonowskiej wizji uporządkowanego świata. Pomimo wszelkich przeobrażeń renesansowego stylu - od manieryzmu poprzez impresjonizm, przestrzeń kreowaną przez artystów nadal traktowano jako jednorodną i regularną. Pozostawała rozumową i podlegającą regułom całością. Zauważamy to, patrząc na przykład na barok, rokoko czy manieryzm. Style te przekładają się na techniki odpowiadające podskórnym składnikom cywilizacji. Są one postrzegane, ale rzadko uświadamiane. Przenikają wszystkie oblicza kultury, choć przejawiają się w różny sposób.

W muzyce unikalną cechą Zachodu było wprowadzenie akordów harmonicznych, co nadało uporządkowaną strukturę interwałom dźwiękowym, które jednoczyły rytm i melodię w strukturalną harmonię i równoważyły melodię z them akordów.

Przy bardziej dogłębnym ujęciu każda kultura daje się zamknąć w jakieś ramy, jest spójna, dlatego też można o niej orzekać. Kultura świecka pomimo tego, że ma pewne swoje podskórne rytmy i atmosferę, nie odznacza się zazwyczaj tak świadomym zamysłem jak kultura religijna. Ta charakteryzuje się większą spójnością, wszystkie bowiem jej części kierują się ku wspólnemu celowi: ku tajemnicy Boga, ku wzniosłości, budzeniu grozy i transcendencji. Wspólność ta, niczym jedna nić, łączy architekturę, malarstwo, literaturę i muzykę. Żyje w niej przekonanie wedle myśli Arystotelesa, a później św. Tomasza z Akwinu czy Mistrza Eckharta, którzy twierdzili, że malarz pracował na bazie ,idealnego obrazu w swej duszy”3. Takie zakorzenienie w doświadczeniu przygotowywało społeczeństwa na klęski i dawało zarazem jakąś ponadczasową wizję rzeczywistości. Współcześnie, szukając opoki dla myśli klasycznej, trzeba by wskazać na, wyróżnianą przez krytyków, kulturę wysoką (poważną). Jej zwyrodnieniem, wynaturzeniem jest kultura rozrywkowa (masowa, popularna, obrazkowa) zwana przez uprzejmość niską.

\section{Korzenie zmian}

Klucz do zrozumienia zjawisk, które mają miejsce w kulturze ostatnich 200 lat i negują wyżej przedstawione podejście, Bloom dostrzega w mowie De hominis dignitate Pico Della Mirandoli, w której padają następujące słowa:

„Nie uczyniliśmy ciebie ani istotą niebiańską, ani ziemską, ani śmiertelną, ani nieśmiertelną, byś sam siebie, niczym wolny i z nadania rzeź-

\footnotetext{
${ }^{3}$ Por. Bell, op. cit., s. 145-146.
} 
biarz oraz twórca, wyraził w formie, którą nad inne podłożysz. Możesz wyrodzić się w niższe stworzenia, w zwierzęta, możesz zostać odrodzony dzięki postanowieniom twojego umysłu w istotach wyższych i boskich"4.

Pojęcie „godności człowieka” ukute przez autora już w XV wieku miało wydźwięk bluźnierczy. Istota ludzka nie była wcześniej rozumiana jako szczególnie godna, gdyż godność posiadał Bóg, człowiek zaś był jedynie stworzony z prochu na Jego podobieństwo.

Najbardziej znaczącymi zdarzeniami dla myślenia o sztuce były rewolucja francuska i amerykańska. Bloom zajmuje się studiami nad tym okresem. Podwaliny pod zmiany zostały wcześniej położone w pismach Hobbesa, Locke'a i Rousseau. Zgłębili nowo odkryte terytorium, zwane stanem natury. Zamieszkiwali je niegdyś nasi antenaci. Wyniki ich badań przynosiły ważną nową informację: z natury wszyscy ludzie są wolni i równi. Tego rodzaju wiadomość stymulowała rewolucje, podważając absolutny autorytet władzy. Wielkie osiągniecie polityczne ma na swoim koncie Locke, mianowicie na podstawie jego zaleceń zostały ukonstytuowane nowe ustroje Anglii i Ameryki. Fundamenty społeczeństwa obywatelskiego wyprowadzone zostały właśnie z baśni o stanie natury. „Oświeceni” udali się ku początkom, a nie ku końcowi, jak to czynili dawniejsi myśliciele polityczni. Sokrates wyobraził w słowach państwo doskonałe; Hobbes odkrył wyizolowaną jednostkę, której życie było „samotne, nędzne, okrutne i krótkie”. Hobbes, Locke i Rousseau byli zdania, że celem społeczeństwa obywatelskiego nie jest wspieranie człowieka w jego przyrodzonym dążeniu do doskonałości, lecz redukowanie konfliktów tam, gdzie ułomność natury zmierza do wojny. Oświecenie pragnęło rozciągnąć na wszystkich ludzi przywilej garstki - życia przeżywanego zgodnie z rozumem. Szlachetne przykazanie, byśmy kochali naszych bliźnich, wymagało od nas wygórowanych, sprzecznych z naturą obowiązków, rzekomo zasłaniając nasze rzeczywiste problemy. Niepotrzebna jest miłość bliźniego czy wiara, nadzieja i miłość, lecz samolubna, egoistyczna praca kierowana rozumem. Z punktu widzenia dobrobytu człowieka potrzebni są nie święci praktykujący cnoty, lecz ludzie zdolni ocenić, co jest dla nich korzystne. Ich przeciwieństwem nie są ludzie źli, występni czy grzeszni. Są to tzw. kłótnicy i pasożyci. Do kłótników i pasożytów mogą się zaliczać nie tylko tumani i kloszardzi, lecz także duchowni i arystokraci.

Innym kluczowym terminem odkrytym i zdefiniowanym we współczesnym sensie przez badaczy stanu natury jest jaźń. Pozwala nam poznać, kim naprawdę jesteśmy. Ludzie są jaźniami i całe ich postępowanie służy zaspokojeniu lub

${ }^{4}$ G. Pico della Mirandola, Oratio de hominis dignitate, mowa o godności człowieka, thum. Z. Nerczuk i M. Olszewski, Warszawa 2010, s. 39 (pag. 22-23). 
spełnieniu ja. Kwestie te jednak wymykają się precyzyjnym definicjom. Czy to, co kryje się pod słowem jaźń, może stać się nowoczesnym surogatem duszy?

Idąc tropem renesansowej idei człowieka, który posiadł umiejętność swobodnego nadawania sobie dowolnego kształtu, natrafiamy w XIX wieku na punkt zwrotny w pojmowaniu sztuki, mianowicie sformułowanie koncepcji awangardy. Pochodzi ono od Henriego de Saint-Simon. Obserwując odrzucanie chrześcijaństwa, a co za tym idzie zapotrzebowanie na wprowadzenie nowego kultu, postanawia utworzyć własny. Jego przedmiotem ma być właśnie sztuka. Artysta objawiać będzie społeczeństwu wspaniałą przyszłość i ekscytować ludzi wizją nowej cywilizacji. W dialogu między artystą a uczonym Saint-Simon nadał terminowi „awangarda” jego współczesne, kulturowe znaczenie:

„To my, artyści, posłużymy wam za awangardę; potęga sztuki jest w istocie i bardziej bezpośrednia, i skuteczniejsza; kiedy chcemy rozpowszechnić nowe idee wśród ludzi, zapisujemy je w granicie lub na płótnie; [...] Odwołujemy się do wyobraźni i uczuć ludzkich, toteż powodować powinniśmy zawsze najżywsze i najbardziej decydujące działanie. [...]

Czyż sztuka może mieć piękniejsze przeznaczenie, niż wywieranie pozytywnego wpływu na ludzi, pełnienie prawdziwie kapłańskiej funkcji, zdecydowane przewodzenie wszystkim zdolnościom intelektu swej epoki w imię ich najpełniejszego rozwoju! Taki jest obowiązek artystów, na tym polega ich misja"s.

W późniejszym czasie wnioski z doktryny mistrza wyciąga jego uczeń August Comte w swoim drugim wielkim dziele pt. System polityki pozytywnej. Tezy tam zawarte pokazują, że głównym zadaniem filozofii pozytywistycznej jest usystematyzowanie całej ludzkiej egzystencji wokół jej prawdziwego źródła, czyli uczuć. Cel jest jasny - podważenie wszystkich religii świata. Nie bagatelizując roli Klotyldy de Vaux ${ }^{6}$, która będąc muzą filozofa, przyczyniła się do przyspieszenia jego prac, w powstawaniu idei naczelną rolę pełnił Saint-Simon. Są to podwaliny pod ruchy artystyczne, które były apogeum modernizmu.

\section{Krystalizacja nowego spojrzenia}

Lata 1890-1930 były wielką epoką modernizmu, jego eksperymentów stylowych i formalnych. Rodziły się wtedy nowe kierunki rewolucyjne takie, jak:

\footnotetext{
${ }^{5}$ H. de Saint-Simon, Opinions litteraires, philosophiques, et industrialles. [Za:] Bell, op. cit., s. 70.

${ }^{6}$ Por. E. Gilson, Szkoła muz, tłum. B. Majchrzak, Warszawa 1965, s. 125-158.
} 
futuryzm, imagizm, konstruktywizm, dadaizm, surrealizm, abstrakcjonizm. Wraz ze zmianami rozszerzył się zakres wolności artystów, co ma zawsze pewne dobre strony, jednak prawo swobodnej ekspansji osobowości w sztuce jest szczególnie płodne, kiedy dokonująca tej ekspansji osobowość jest interesująca. Istnieje ryzyko, że wolność taka jest fatalna, kiedy wyrażane uczucia są zwyczajnie płytkie. Jak znaleźć dobrą miarę, by być zarówno interesującym człowiekiem i interesującym artystą? Często bywa tak, że w sztukach za pomocą znakomitych środków wyrazu przekazuje się nam uczucia, które hiszpański filozof nazwałby uczuciami „subiekta ze składu mydlarskiego”. Mielibyśmy te odczucia, co więcej, podzielać. Na jakie zmiany, które wnosi modernizm, zwraca uwagę Ortega y Gasset? Ich znaczący przejaw to dehumanizacja. Napisał, że: „Musimy wymyślać karkołomne łamańce, by przystosować się do tych osobliwych postaci" niści wysadzili za sobą mosty, gdzie zostawili rzeczywistość ludzką. W nowych tendencjach zaznacza się niechęć do form tworzonych przez życie, praktykowanie sztuki tylko jako zabawy oraz postawa ironiczna. Według młodych twórców sztuka ma być pozbawiona jakiegokolwiek transcendentnego znaczenia.

Powstaje nihilizm, który jako stan duszy objawia się nie tylko brakiem zdecydowanych przekonań, lecz chaosem instynktów i odczuć. W społeczeństwie znika wiara w naturalną hierarchię złożonych i wzajemnie sprzecznych popędów duszy. Tradycja, która dotychczas wyręczała naturę w tym zadaniu, runęła. Bloom pisze o duszy, że

„[...] staje się sceną teatru, który regularnie zmienia repertuar - raz grają tragedię, raz komedię; jednego dnia o miłości, innego o polityce, jeszcze innego o religii; niektóre sztuki są kosmopolityczne, niektóre patriotyczne; niektóre indywidualistyczne, niektóre społeczne; niektóre sentymentalne, niektóre brutalne. Nie istnieje ani zasada porządkująca, ani wola, by poddać repertuar jakiejś hierarchii”».

Z punktu widzenia Nietzschego szalony bal kostiumowy namiętności bez wątpienia zmierza do rozkładu jedności duszy i osobowości, co skończy się ostateczną psychiczną entropią.

Ponadto Bell zwraca uwagę na fakt, że pod koniec XIX wieku próbowano wpłynąć na tradycyjne pojęcie czasu - chrześcijańskie creatio ex nihilo. Konsekwencją tego było wyrugowanie refleksji na temat wieczności, zmiana pojmowania teraźniejszości rozumianej jako to wszystko, co nas otacza, łącznie z nami,

\footnotetext{
${ }^{7}$ Ortega y Gasset, op. cit., s. 193.

${ }^{8}$ A. Bloom, Umyst zamknięty. O tym jak amerykańskie szkolnictwo wyższe zawiodto demokrację i zubożyło dusze dzisiejszych studentów, tłum. T. Bieroń, Poznań 1997, s. 181.
} 
istniejąc tylko w jednym niepodzielnym momencie i wskazując na nasze istnienie. W ramach konwencji językowych próbowano ująć sens życia jako strumień świadomości. Określenie to zostało ukute przez Williama Jamesa i pojawia się w jego Principles of Psychology z 1890 roku. Pojęcie strumienia świadomości implikuje, że nawet tam, gdzie mamy do czynienia z przerwą w czasie, świadomość po przerwie pokrywa się ze świadomością przed nią - a więc, że czas doświadczany jest nie chronologicznie, lecz symultanicznie. Równie istotne dla naszego rozumienia znaczenia jest to, iż kiedy doświadczamy czasu jako strumienia świadomości, fragmenty tego strumienia mają tyle znaczenia i takież oddziaływanie, jak punkty oznaczające jakieś rzeczywiste całości. Taka specjalizacja formy przerywa upływ czasu w narracji, by skoncentrować się na relacjach zachodzących w unieruchomionym interwale czasowym. Pomysł ten ma swoje odbicie na polu literatury, stanowiąc sedno eksperymentów Gertrudy Stein, Jamesa Joyce'a czy Virginii Woolf. Polega na zanurzeniu czytelnika w samym strumieniu czasu. Ulisses Joyce'a z wielkim kunsztem przedstawia asamblaż czasu i uwypukla zmianę perspektywy nie tylko przez przytaczanie przeszłych scen, lecz również dzięki wyróżniającemu się charakterowi następnych rozdziałów, co wskazuje, że historia może pójsćc różnymi drogami9.

Podobnie zmienia się postrzeganie muzyki. W stylu modernistycznym uwidacznia się obsesja dźwięku, czyli uwypuklenie pierwszego planu muzycznego. Dobrym przykładem jest różnica zachodząca między Wagnerem a Schoenbergiem, pokazująca, w którą stronę kierują się zmiany. W młodzieńczych utworach Schoenberga widoczne są wpływy mistrza Wagnera, kiedy później odrzuca użycie harmonijnego tła, stosując zasadę strukturalną wyłącznie do pierwszego planu. Była to droga do odrzucenia klasycznych konwencji czasowych. Kolejni kompozytorzy rozwijający idee awangardy zajmowali się elementami aleatorycznymi, czy nawet ciszą, a szczyt absurdu osiągnął John Cage utworem 4'33, który składa się z zapisanych na partyturze pauz.

Podczas konferencji „Polityczne Konteksty Sztuki”, która odbyła się w Kazimierzu Dolnym w 2011 roku, której efektem jest tenże artykuł, doszło do ciekawej polemiki z prof. dr. hab. Tadeuszem Szkołutem na temat eseju Ortegi y Gasseta z 1925 roku pt. Dehumanizacja sztuki. Mianowicie nie zgadzam się ze zdaniem pana profesora, który twierdzi, jakoby w tym tekście autor pokazywał uwielbienie i entuzjazm dla nowej sztuki. Takie podejście jest tożsame z modernizmem. Nietzsche doszedł w swoich rozważaniach do tak skrajnych tez, że tekst nie istnieje, istnieje tylko jego interpretacja. Współcześnie tego typu rozważania posuwają się dalej ku popularnemu poglądowi, że zamiast bytu istnieje jedynie

\footnotetext{
${ }^{9}$ Por. Bell, op. cit., s. 145-155.
} 
widziane z różnych stron stawanie się. Wszystko co jest, jest tym, co postrzegane, jest tym, czym się wydaje. Ergo, nie warto zagłębiać się w możliwość takiej interpretacji - ten rodzaj analizy ma nierzadko więcej wspólnego z fantazją i manipulacją. Sprawą zasadniczą, o której często się dziś zapomina, w tym wypadku jest prawda słów, o której pisał Roger Schattuck „Prawdziwie klasyczny styl pisarstwa wymagał, by każde słowo miało jedno, jasne znaczenie w każdym kontekście. [Tak np. wedle La Bruyere’a: „Spośród rozmaitych wrażeń, które oddać mogą jakąś naszą ideę, jedno tylko jest trafne, prawdziwe]"10. Powracając do sedna sprawy: jaka więc jest postawa hiszpańskiego filozofa? Ortega y Gasset napisał: „Nie jest moim zamiarem wielbienie nowej sztuki [...] Ograniczam się jedynie do określania ich [rodzajów sztuki - przyp. autora] w taki sposób w jaki zoolog określa dwa różne gatunki”" ${ }^{\prime 1}$. Autor eseju również w zakończeniu z naukową precyzją pisze o tym, że kierował się zrozumieniem czegoś, a nie gniewem czy entuzjazmem. Czy więc nie jest jego dążeniem ukazanie w pełnym świetle obrazu nowej sztuki, w miarę możliwości wniknięcie w jej istotowe założenia? $\mathrm{Z}$ całą pewnością w toku swojego wywodu pokazuje, co twórca awangardowy traci przez dążenie do nowego. Na temat liryki padły następujące słowa:

,[...] czy w nowej poezji gdzie metafora pełni funkcję zasadniczą, a nie tylko dekoracyjną, nie pomniejsza ona jednocześnie i nie lekceważy rzeczywistości, zamiast ją uszlachetniać i wywyższać. [...] Ostrze poezji zwróciło się przeciwko rzeczom naturalnym, kalecząc je i zabijając"12.

Na czym więc chcą budować nowi artyści? Pogardzają oni radością, smutkiem, śmiechem i łzami, chcąc tworzyć z niczego. Takie odrealnienie prowadzi do fatalnego pomieszania pojęć, kiedy nie wiemy, czy „przeżywać” rzeczy, czy je obserwować. Reasumując - do jakich wniosków dochodzi Ortega y Gasset? Myśl, którą formułuje, wprowadza go niemalże w osłupienie. Sztuka jako taka jest przecież sumą zgromadzonych doświadczeń artystycznych. Czy więc zwrócenie się przeciwko sztuce przeszłości nie jest atakiem na sztukę w ogóle? Wniosek ten jest przejmujący. Autor eseju, idąc tym tokiem rozumowania, doszedł do dalszych konsekwencji tego podejścia - „Nienawiść do sztuki może się rozwinąć jedynie tam, gdzie istnieje nienawiść do nauki, do państwa, czyli po prostu nienawiść do całej kultury i cywilizacji”" ${ }^{\prime 3}$. W zakończeniu eseju przedstawił pogląd, że nowa sztuka nie reprezentowała sobą nic naprawdę godnego uwagi.

\footnotetext{
${ }^{10}$ R. Schattuck, The Banquet Years, New York 1968, s. 36. [Za:] Bell, op. cit.

${ }^{11}$ Ortega y Gasset, op. cit., s. 185.

${ }^{12}$ Ibid., s. 204.

${ }^{13}$ Ibid., s. 213.
} 


\section{Psychodeliczny bazar}

Jak wyewoluowała odpowiedź na klasyczne pytanie „Kim jesteś”? Zgodnie $\mathrm{z}$ tradycją brzmiałaby „Jestem synem swojego ojca”. Jest to widoczne w rosyjskich patronimikach, czy też w starych nazwiskach angielskich, np. Johnson. W latach 60. XX w. odpowiedź przybrała formę: „Ja jestem sobą, sam o sobie świadczę tym, co robię i co wybieram". Jednym z najwyraźniejszych znamion nowoczesności jest właśnie ta zmiana samoidentyfikacji. Dawne fundamenty tożsamości takie, jak autorytet, tradycja, prawda objawiona czy nawet rozum przeminęły na rzecz doświadczenia. To ono przybrało rangę źródła wiedzy i układu odniesienia wobec innych ludzi.

Religia narzucała społeczeństwu pewne normy. W sytuacji, gdy najwyższą wartością staje się doświadczanie samego siebie, przedmiotem badania jest niemalże wszystko. Pojawia się absurd: jedyną drogą do stworzenia wspólnoty jest wspólne doświadczenie. Właśnie ono staje się kryterium, które jest próbą odnalezienia wspólnego języka. Kultura sprzęgła się z tym, co demoniczne, tworząc postulat autonomii estetyki. Istotą modernizmu było wykroczenie poza religie. Autorytet został przeniesiony ze sfery sacrum do profanum ${ }^{14}$.

W społeczeństwie, które bazuje na wyjałowionych wierzeniach, szybko jako norma rozprzestrzenia się styl życia kulturalnych mas. Masy chcą dokonać transgresji czy też „wyzwolić się”, lecz na drodze stoi przeszkoda. Brakuje im moralnych prawideł, które byłyby w stanie wyjaśnić, na czym polega to wartościowe doświadczenie. Wrażliwość, jaką pokazały lata 60., wskazując na wyczerpanie modernizmu, jest świadectwem zużycia estetyki szoku i sensacji, która stała się nudna i trywialna. Widoczny jest proces przekształcania się modernizmu w rozmaite odmiany postmodernizmu, który przez Bella określany jest wprost jako [...] psychodeliczny wysiłek bezgranicznego rozszerzania świadomości prowadzący po prostu do rozkładu osobowości poprzez zniesienie indywidualnego ego" ${ }^{15}$. Obserwacje te rozwija, twierdząc, że współczesność rozbija dotychczasową jedność w kilku aspektach: odrywając estetykę od norm moralnych, w coraz większym cenieniu tego, co nowe i eksperymentalne oraz w uznaniu, że osoba wyznaczająca sądy kulturowe jest jednostką poszukującą oryginalności i niepowtarzalności. $\mathrm{Z}$ autonomii estetyki zrodziła się idea, iż każde doświadczenie zewnętrzne i wewnętrzne jest wartością najwyższą, że wszystko powinno podlegać badaniu i wszystko winno być dozwolone - przynajmniej w wyobraźni, jeśli nie w życiu praktycznym.

\footnotetext{
${ }^{14}$ Bell, op. cit., s. 124-128.

${ }^{15}$ Ibid., s. 64.
} 
Patrząc na pojmowanie sztuki, cechy wspólne teorii estetyki, jej punktem zasadniczym było zniszczenie pojęcia przedmiotu. Według Harolda Rosenberga ważne było zdefiniowanie sensu malarstwa jako „działania”. Znaczy to, że obraz artysty sam w sobie nie zawiera wartości malarskiej, lecz zależy ona od czynności malarza, który go tworzy. Wynika z tego, że widz ma dopatrywać się istoty rzeczy nie w obrazie, lecz w czynnościach kinestetycznych, które towarzyszyły jego powstawaniu. Próby te zmieniały koncepcje trwania sztuki i kładły nacisk bardziej na pamięć niż na sam przedmiot, nie zostawiały jednak niczego, co warte by było zapamiętania.

Przykładem są environments autorstwa Roberta Rauschenberga, w których ekspozycja rzeźby jest przypadkowa - zależy od wagi i ciepłoty ciała widza. Dalszym „rozwojem” malarstwa jest przekształcanie go w happening, jak to miało miejsce w przypadku Yvesa Kleina. Jest to kolejny krok do zatarcia granicy między życiem i sztuką - kolejny etap mieszania się gatunków. Każde doświadczenie może się przekształcić w sztukę. Bell skonstatował: „Celebrując życie, proces ten zmierzał do zniszczenia sztuki”'16. Widocznie zarysowuje się wynoszenie tego, co „naturalne" ponad to, co wykoncypowane, szczerości ponad ocenę, a spontaniczności ponad refleksję. Lata 60. w dalszym ciągu rozbijały ludzką jaźń poprzez nowe podziały. Roger Shattuck wyróżnia cztery cechy nowego jej przedstawiania: kult dzieciństwa, fascynacja absurdem, cenienie popędów niskich, zaciekawienie halucynacją. Przykładem jest twórczość Williama Burroughsa, która niemalże kompletnie odwraca wartości. Radość lektury miała płynąć z celebrowania tego, co niskie. Afirmuje się narkotyki i doświadczanie przeżyć niskich. Nawet własna jaźń przestała być dla pisarza układem odniesienia. Czytając pisarzy reprezentatywnych dla tego okresu, dochodzi się do wniosku, że głównym przedmiotem ich zainteresowania było szaleństwo. Kiedy zaprzestano zajmowania się życiem społecznym, a podmiot uległ rozmyciu, każdy niemal znaczący pisarz tego okresu w jakiś sposób podejmował ten temat. Powieści mają charakter halucynacyjny. Wielu ich bohaterów to schizofrenicy: probierzem rzeczywistości jest w nich raczej obłąkanie niż normalność. Pomimo wszystkich społecznych niepokojów lat 60., głucho o nich w powieściach tych pisarzy. W fantastycznych i futurystycznych powieściach Anthony'ego Burgessa, czy Kurta Vonneguta w miarę jak postacie ulegają rzeczywistym fizycznym przemianom, następuje spiętrzenie absurdów. Podkreślają one bezsensowność wydarzeń i zacierają różnicę między dobrem a złem ${ }^{17}$.

Kolejnym krokiem do zniszczenia starego świata była próba zniesienia podziału na sztukę wysoką i niską, jednego z ostatnich jego bastionów. Słynna lewicowa

\footnotetext{
${ }^{16}$ Ibid., s. 158.

${ }^{17}$ Por. Bell, op. cit., s. 156-164.
} 
Pobrane z czasopisma Annales L - Artes http://artes.annales.umcs.pl

Data: 26/04/2023 06:58:32

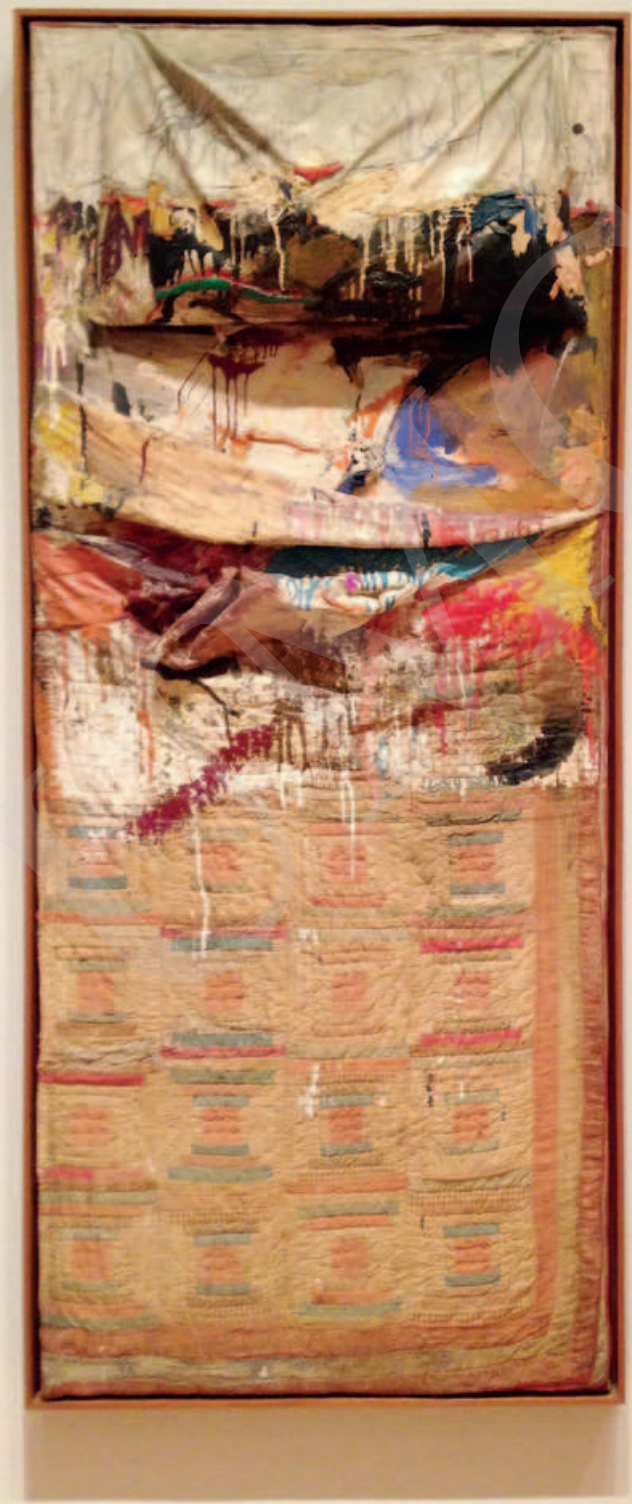

Ilustr. 3. Robert Rauschenberg, Łóżko, 1955, źródło: flickr.com. 
intelektualistka Susan Sontag posunęła się do tego, by twierdzić, że podział ten jest związany z różnicą „przedmiotów unikalnych od produkowanych masowo”. W książce Against interpretation widać działania prowadzące do rozmycia rzeczywistości i zredukowania wielowymiarowości ludzkiej:

„Liczą się wrażenia, uczucia, abstrakcyjne formy i style wrażliwości. Do nich adresowana jest nowoczesna sztuka [...] jesteśmy o wiele bardziej i głębiej tym, co potrafimy widzieć (słyszeć, smakować, wąchać, dotykać), niż tym, o czym świadczą składowane w naszych głowach idee"18.

Syntetyzując: radykalny egalitaryzm uczuć zastępuje starą hierarchię myśli. Bell pisze również o tzw. demokratyzacji geniuszu. Przyczyną jest właśnie rosnąca rola uczuć, o które, w przeciwieństwie do opinii, nie można się spierać. Dzieło sztuki bądź wywołuje w nas emocje, bądź nie, a czyjeś uczucia nie są autorytetem dla kogoś innego, są relatywne. Ponadto, wraz z upowszechnieniem wyższego wykształcenia i rozszerzeniem warstwy na wpół zawodowej inteligencji, znacznej zmianie uległa też i skala zjawiska. Wielu ludzi dotąd obojętnych domaga się dziś prawa do uczestniczenia w życiu artystycznym - $\mathrm{i}$ to nie dla doskonalenia swego umysłu czy wrażliwości, lecz aby „zrealizować” swą osobowość. Zarówno w naturze samej sztuki, jak i w reagowaniu na nią, zainteresowanie własną osobą bierze górę nad wszelkimi obiektywnymi kryteriami.

Wszystkie te zmiany prowadzą do ciężkich odkształceń w zakresie całego ludzkiego doświadczenia. Celem jest doprowadzenie do uczuć skrajnych. Doznawanie, bezpośredniość, wielość, działanie jako sposób estetyczny i psychologiczny dąży do doprowadzenia naszego odczuwania do granic wytrzymałości. Co więcej, wszystko to jest pozbawione momentu oczyszczenia - katharsis, co nie powinno zaskakiwać, gdyż kultura ta opiera się bardziej na technice niż na treści. Człowiek zostaje sam na sam ze wspomnieniem wiru odczuć, które prowadziły na skraj szaleństwa. Co może zostać, gdy psychodeliczna chwila przeminie? Jest to podniecenie, dezorientacja i poczucie wyjaławiającej pustki. Akceptacja takich założeń jest wyparciem się wspólnoty ludzkiego doświadczenia.

\section{Powrót do klasyki}

Czas, w którym żyjemy, skłania nas do powtórzenia pytania Archimedesa o punkt oparcia. Odnosi się ono do dwóch kwestii: po pierwsze, czy istnieje niezmienny ludzki charakter i po drugie: jak można oddzielić to, co w nim akcydentalne

\footnotetext{
${ }^{18}$ S. Sontag, Against Interpretation, New York 1966. [Za:] Bell, op. cit., s. 165.
} 
i historyczne, od tego, co stałe i niezmienne. Człowiek nowożytny żyje w świecie przeobrażonym przez abstrakcje, sam stając się przez nie przekształconym - wpędzonym w ślepy zaułek. Jeżeli chce ponownie doświadczyć człowieczeństwa, musi wmyślać się w te abstrakcje przez zwrot ku filozofom, którzy ich nie podzielali, dzięki czemu mogą zaprowadzić nas do doświadczeń, które bez ich pomocy są dla nas trudne bądź niemożliwe do osiągnięcia. Każdy, kto przyjął sobie za misję poszukiwanie samoświadomości, powinien pojąć znaczenie tej zależności. Spójrzmy na współczesne instytucje społeczne. Jak mają się do siebie ich główne cnoty, czyli wolność i równość? Z arystotelesowskiego punktu widzenia możliwy jest inny podział: na równość arytmetyczną, którą stosuje się do wszystkich, oraz równość proporcjonalną, opartą na różnicy zasług. Co natomiast pokazuje ostatnie półwiecze? Zmiany w dystansie socjologicznym, psychologicznym i estetycznym czy duchowym implikują stan, w którym nie ma praw, zasad ani granic, które by porządkowały ludzkie doświadczenia i myśli. Przecież narzucenie odpowiedniego dystansu, chociażby poczucie przeszłości i teraźniejszości - czyli odróżnienie tego, co minęło, od tego, co teraźniejsze, jest jednym ze świadectw dojrzałości. Społeczeństwo coraz bardziej pozbawione jest prawdziwej religii, która zapewniałaby mu zakorzenienie, niezależnie od tego, jak bardzo by wątpiło. Ludzie wykorzenieni skazani są na kulturalne tułactwo i bezdomność. Stan ten Bloom określił w następujący sposób: „Jesteśmy trochę jak barbarzyńcy, którzy pod wpływem misji ewangelicznej nawrócili się na chrześcijaństwo, nie doświadczywszy wszystkiego, co przyszło przed i po objawieniu" ${ }^{\prime \prime}$.

Czy początkowo pozornie niewinna, idea awangardy jeszcze realnie istnieje, a nie stała się pustym pojęciem? Można śmiało powiedzieć, że w naszej postmodernistycznej kulturze niemalże nikt nie broni dziś porządku czy tradycji. Istnieje tylko pęd do nowego - znudzenie zarówno tym, co stare, jak i nowe. Trudno się nie zgodzić z kolejną szarżą Blooma:

„Obecnie antropologowie nie potrafią określić, czym jest kultura, lecz są przekonani o istnieniu tego zjawiska. Artyści nie mają wizji tego, co wzniosłe, lecz wiedzą, że kultura (czyli to, czym się zajmują) ma prawo do poszanowania i wsparcia ze strony społeczeństwa obywatelskiego. Socjologowie oraz propagujący ich poglądy dziennikarze wszystko nazywają kulturą - istnieje kultura narkotyków, kultura rockowa, kultura uliczników i tak dalej, bez żadnego rozgraniczenia. Upadek kultury również jest kulturą"20.

\footnotetext{
${ }^{19}$ Bloom, op. cit., s. 182.

${ }^{20}$ Ibid., s. 218.
} 
Awangarda już nie istnieje! Jedyne, co pozostaje, tym, którzy tego nie zrozumieli, jak expressis verbis diagnozuje Bell: „To patetyczne sławienie własnej, opróżnionej z treści jaźni, udającej żywotność przez odgrywanie rewolucji”21. Powinniśmy wyciągnąć wnioski z rad tych uczonych. Polski klasyk Zbigniew Herbert, obserwując powstawanie III RP, mówił o pseudosztuce, której potworki powstają w zamiarze szerzenia nowej propagandy, a nie ze względu na jakiekolwiek zapotrzebowanie. Kulturę tworzą elity nazywające się inżynierami a będące w rzeczywistości fuszerami dusz. Co może przynieść sztuka XXI wieku? Czy są szanse, by właśnie za jej pomocą możliwe było wgryzanie się w złudne abstrakcje współczesnego świata? Warto rozważyć takie rozwiązanie uwzględniające młodą sztukę polską. Ze szczególnym naciskiem na jej polskość i uniwersalność narodowości jako takiej. Jej potencjalne zadania byłyby wielowymiarowe - związane z edukacją o naszej tożsamości przez kontemplację ojczystej kultury, jak i jej historycznego tła. $Z$ drugiej strony walka z ludzkim zobojętnieniem, nieufnością, które zagościły w duchowej pustce społeczeństw demoliberalnych. Jest to temat na osobne rozważania. Ciągłe ślepe kopiowanie wzorców z Zachodu i zawiadywanie światem sztuki przez subkulturę kuratorów i krytyków ewidentnie skutkuje dalszym impasem. Sprzeciwienie się temu paradygmatowi, kompetentna refleksja i odnowa wspólnoty zależy tylko od nas.

\section{SUMMARY}

The starting point for the analysis is an anxiety associated with the vanishing of the foundations of European culture. In the classical paradigm, the artist worked on the basis of an ideal image that $\mathrm{s} / \mathrm{he}$ carried in his/her soul. However, this vision was rejected. Modernity offered rationalism, freedom, and equality to the humankind. The result of this fundamental change is the so-called "psychedelic bazaar" - a certain form of culture continually offering new, surprising and often extreme experiences. By following them, a person is disoriented and his/her feeling is driven to the breaking point. Consequently, $\mathrm{s} / \mathrm{he}$ is like an uprooted being condemned to cultural wandering. The way out of this impasse is to return to Archimedes' question about the point of support, and to ponder over the invariable in human culture and the accidental and transitory.

\footnotetext{
${ }^{21}$ Bell, op. cit., s. 180.
} 